Nasadyuk C. M.

\title{
PLACENTAL STEM CELLS: BIOLOGICAL CHARACTERISTICS AND APPROACHES TO CLINICAL APPLICATION
}

\section{ABSTRACT}

Literary data gives evidence that placenta is a rich source of stem cells that phenotypically correspond to human mesenchymal stem cells. The possibility of osteogenic and hepatogenic differentiation of placental mesenchymal stem cells was reported as well as their transformation into cardiomyocytes, adipocytes was shown. It was established that mesenchymal stem cells of placenta have the highest potential of osteogenic differentiation compared to the stem cells from other sources. The advantages of placental stem cells towards clinical application are ethical feasibility and non-invasive collection, high proliferative potential and immunomodulatory properties.

KEYWORDS: placental stem cells; regenerative medicine

The placenta as a valuable initial product for the manufacturing of medicinal products represented interest yet for physicians of the elder times, and the tradition to preserve dried placenta was common in many ancient peoples [2]. Long before the description of the biochemical and cytological composition of the placenta, placental preparations were widely used to stimulate wound healing [2, 8].

The placenta contains a large number of important biologically active substances, including vasculoendothelial and epidermal growth factors, transforming growth factor-beta, fibroblasts growth factor, some hormones, anticoagulants, enzymes, minerals and vitamins [2, 8, 21, 23]. Placental extracts exert immunoregulatory, regenerative, neuroprotective, anti-inflammatory, analgesic properties, may have anti-allergic and antitumor effects, normalize hormonal function in women [2]. Based on placental extracts numerous drugs were developed and commercialized, which to date are widely used in modern medicine and cosmetology. [8] Amniotic membrane of the placenta is used in the treatment of wounds, burns, lesions of the oral mucosa [20].

Placental or, as it is more often called, umbilical cord blood is recognized as a transplant of hematopoietic stem cells, alternative to bone marrow [1, 3, 4]. In 2013, more than 30,000 transplants of umbilical cord blood hematopoietic stem cells were performed worldwide [5]. However, in the last decade, placental tissue was shown to be not less valuable source of hematopoietic and mesenchymal stem cells for potential use in medical practice $[7,15,28]$.

Mesenchymal stem cells of the placenta ontogenetically are similar to embryonic stem cells, but their collection and use are absolutely ethical, non-invasive and economical $[20,22]$. Placental mesenchymal stem cells were also shown to have a higher plasticity and a higher ability to proliferation compared with stem cells isolated from adult tissues $[10,14,20]$. Phenotype of placental mesenchymal stem cells depending on the location is similar to those of bone marrow and adipose tissue [14]. Mesenchymal stem cells isolated from chorionic villi of full-term human placentas expressed CD44, CD90, CD105, CD146, CD166, HLA$A B C$, very low levels of $C D 29$ and $C D 14$ was not expressed, $C D 19, C D 45$, CD80, CD83, CD86, HLA-DR [14, 24]. Placental mesenchymal stem cells were also shown to secrete cytokines $I L-1 R a, I L-6, I L-8, I L-10$, IL-11, IL-15, some adhesion molecules, chemokines and their receptors, are able to migrate in response to chemotactic factors including stromal cells factor-1, platelet-derived growth factor, hepatocyte growth factor and monocytic chemotactic protein-1 [14].

\section{PLACENTAL MESENCHYMML STEM CELLS}

\section{IN THE BIOENGINEERING OF BONE-CARTILAGINOUS DESIGNS}

The search for an optimal substitute material for bone reconstruction, which could allow to avoid immunological complications, inflammation, distortion is an urgent problem of modern traumatology and orthopedics [21]. Nonimmunogenic stem cells with chondrogenic potential are being increasingly investigated in this direction [16]. Thus, it is proved that $500 \mathrm{mg}$ of mesenchymal stem cells produce $3 \mathrm{~kg}$ of bone tissues [3]. Placental mesenchymal stem cells are of particular interest for purposes of bioengineering of bone-cartilagineous designs, which as shown by scientists, have a high capacity for osteogenic differentiation [16, 24, 27].

The study on rabbits showed that placental mesenchymal stem cells grow on fibrous silk biomaterials that can be used as a carrier of this 
cell fraction. Silk fibrous complex biomaterial containing mesenchymal stem cells of human placenta was implanted to animals with experimental damage of the knee joint. No signs of degeneration or inflammation in the area of implantation were observed as well as 12 weeks later fibrous silk material was not revealed. The reconstruction of the affected knee joint by the new hyaline cartilage was shown [16].

In another study on the model of segmental osteo-periosteal defects in rabbits the properties of tissue-engineered bone fragments obtained from mesenchymal stem cells of the placenta and bone marrow were compared. Mesenchymal stem cells from the rabbit placentas were isolated by gradient centrifugation and a single-layer cultivation in vitro. Bone marrow stem cells were isolated from hindlimb bones of newborn rabbits. Cells from both sources were characterized by phenotype $C D 44^{+}$ $C D 105^{+}$and $C D 34^{-}, C D 40 L^{-}$, confirming that these were mesenchymal cells. Isolated cells labeled with BrdU were cultivated towards the formation of tissue engineered bone. Osteoperiosteal defects in laboratory animals were filled by the obtained experimental bone implants. 2, 4, 8 and 12 weeks after transplantation, no significant differences between groups of rabbits, which were transplanted these bone structures were revealed due to radiological, histological and immunohistochemical methods of investigations, determination of the activity of alkaline phosphatase and osteocalcin content, as well as examination of biomechanical properties of tissue-engineered bone [10].

Tissue-engineered bones grown from bone marrow stem cells are being explored in clinical trials [10]. Comparability of bone and cartilaginous structures, obtained from bone marrow cells and placenta allows to recommend the latter for clinical research. Indeed, compared to bone marrow, placenta is much more accessible biological material, collection of which does not involve any invasive procedures.

It was also shown that placental extract due to the high content of cytokines and chemokines may serve as a suitable medium for cultivation of fibroblast cells in tissue engineering of bones [21].

\section{APPROACHES TO CLINICAL APPLICATION OF PLACENTAL MESENCHYMAL STEM CELLS IN INTERNAL MEDICINE}

From the perspective of modern science, cell therapy has the potential to change radically ideas about the treatment of cardiovascular diseases and to achieve regeneration of myocardium, what a few years ago was considered impossible [26]. In clinical studies the safety and efficacy of intravenous, intracoronary, transendocardial and epicardial injection of stem cells in the treatment of coronary heart disease, myocardial infarction, cardiomyopathy were shown [26]. Placenta is considered to be an attractive source of stem cells for myocardial regeneration [17, 23, 25]. Thus, in vitro studies showed that cardiomyocytes were obtained from $80 \%$ of placental mesenchymal stem cells [17]. In another study, induced placental cells on the 20th day of cultivation expressed alphasarcomeric actin and antibodies to cardiac troponin [17].

Studies on mice with experimental myocardial infarction showed high therapeutic efficacy of recombinant human placental growth factor, which is a homologue of vascular endothelial growth factor. Introduction of placental growth factor increased the survival rate of the animals and helped to preserve the functional capacity of myocardium at a level close to the control animals [25].

On a standard model of limb ischemia in mice the use of mesenchymal stem cells of human placenta cultivated in the bioreactor was shown to improve significantly blood flow, reduce oxidative stress and the degree of endothelial damage [23].

Thus, these experimental studies give evidence that the use of placental stem cells is promising in the treatment of cardiovascular diseases.

Comparative studies of differentiation of mesenchymal stem cells of the placenta, bone marrow, adipose tissue and umbilical cord blood into hepatocytes showed that placental mesenchymal stem cells had the most pronounced proliferative potential as well as the highest level of expression of hepatocyte markers compared with cells of the aforementioned sources. After hepatogenic differentiation, expression of hepatocyte growth factor in placental stem cells increased [15].

Comparative study of immunomodulatory effects of stem cells of placenta, bone marrow and adipose tissue showed that placental stem cells are characterized by higher levels of expression of $H L A-A B C$ and $H L A-G$, as well as the cytokines $I L-2, I L-4, I L-13$ and granulocytemacrophage colony-stimulating growth factor. The researchers conclude that the immunomodulatory properties of placental mesenchymal stem cells are the additional benefit of their application in clinical practice [14].

\section{APPROACHES TO CLINICAL APPLICATION OF MESENCHYMAL STEM CELLS OF THE PLACENTA IN THE TREATMENT OF NERVOUS SYSTEM DISEASES}

In an international registry of clinical trials, nearly 150 projects on the evaluation of the safety and efficacy of cell therapy in the treatment of nervous system diseases - cerebral palsy, stroke, Parkinson's disease, Alzheimer's disease, autism and others are registered. [29].

In Parkinson's disease a progressive loss of dopaminergic neurons in mesencephalic black matter of the brain occurs. The conventional treatment of Parkinson's disease is the use of $\mathrm{L}$ - dihydroxyphenylalanine, but the latter is characterized by numerous side effects. Alternatively to L- dihydroxyphenylalanine, efficacy of fetal mesencephalic tissue was shown but the origin of this biological material stipulate the search for more ethical cell transplants with the same high capacity for self-renewal and differentiation [22].

On a model of Parkinson's disease in rats the effectiveness of transplantation of neural precursor cells derived in vitro from placental mesenchymal stem cells in the corpus striatum was investigated. After 2 weeks in experimental animals decrease of rotational asymmetry was noted, and 24 weeks after transplantation almost normal motor function was achieved. Dopaminergic differentiation of transplanted cells was demonstrated immunohistochemically and by method of positron emission tomography. Thus, the authors conclude that the placenta is a potential source of stem cells for the treatment of neurological diseases [22]. Another study confirmed the differentiation of placental stem cells into cells expressing neuronal markers and producing dopamine, preservation of normal karyotype during cultivation was also shown [19].

Placental stem cells injected 4 hours after experimental stroke significantly improved functional status of rats, respectably reduced the area of brain damage, increased level of expression of vasculoendothelial growth factor in zone of ischemic damage [9].

In experimental encephalomyelitis, which is a murine model of multiple sclerosis, the efficacy of intracerebellar transplantation of mesenchymal stem cells of the placenta 5 and 10 days after induction of disease was studied. Investigations of experimental animals during 1 month allowed to mark a significant improvement in mice who underwent cell therapy compared to a placebo effect. Therapeutic effect of intracerebellar transplantation of placental mesenchymal stem cells the scientists associated with reduced levels of proinflammatory protein TSG-6 [12]. Neuroprotective and immunomodulatory effect of mesenchymal stem cells in experimental multiple sclerosis was shown by other authors too [6].

Placental mesenchymal stem cells were also revealed to exert prominent anti-age impact and positive effect on the life span of experimental animals. Female mice $(n=50)$ were divided into 3 groups: control and two experimental groups $B$ and $C$, which were intraperitoneally injected stem cells isolated from their own placentas in the age of 15 months. Both research groups were injected placental mesenchymal stem cells three times at intervals of 10 days, after that group $\mathrm{C}$ was continued administration of stem cells until death. Mice were performed electrocardiography, internal organs of animals were examined by ultrasonography and histopathologically, the activity of antioxidant enzymes (superoxide dismutase, glutathione peroxidase) 
and the intensity of lipid peroxidation in terms of malonic aldehyde were determined. Stem cells were found in many organs of the animals from groups B and C. The life span of mice of group B was 1.7-fold longer compared to control animals, which were not performed cell therapy, however, there was no difference in life span between groups B and C. The use of placental stem cells was shown to prevent the impair of cardiac function, increased antioxidant defense, reduced intensity of lipid peroxidation [18].

\section{CONCLUSION}

THUS, DATA OF EXPERIMENTAL AND CLINICAL STUDIES SUGGEST THAT TODAY BOTH FUNDAMENTAL PREREQUISITES FOR THE USE OF PLACENTAL MESENCHYMAL STEM CELLS IN THE TREATMENT OF MANY DISEASES ARE ESTABLISHED AND IN SOME NOSOLOGICAL UNITS A POSITIVE CLINICAL EXPERIENCE HAS ALREADY BEEN ACCUMULATED.

THE CAUTION FOR CLINICAL USE OF PLACENTAL STEM CELLS IS THAT THE ENTIRE TISSUE OF THE PLACENTA CONTAINS, IN ADDITION TO THE MATERNAL CELLS, FETAL CELLS [11]. DEVELOPMENT OF CELL DRUGS ACCORDING TO GMP STANDARDS, MEETING THE DEMANDS OF INTERNATIONAL ORGANIZATION FOR STANDARDIZATION IS AN IMPORTANT PRECONDITION FOR THE APPLICATION OF PLACENTAL STEM CELLS IN CLINICAL PRACTICE [13].

\section{REFERENCES}

1. Nasadyuk CM. Kletochnye tehnologii v reproduktologii, akusherstve i ginekologii [Cell Technology in Reproduction, Obstetrics and Gynecology]. Kletochnaja i organnaja transplantologija - Cell and organ transplantology, 2013; 1(1):56-60.

2. Nasadyuk CM. Biohimichna harakteristika ta pidhodi do zastosuvannja ekstraktiv placenti v medichnij praktici [Biochemical characteristics and approaches to the use of placental extracts in medical practice]. 3 турботою про жінку - Caring for woman, 2013; 4(43): 54-56.

3. Nasadyuk CM. Pupovinna krov: mediko-biologichna harakteristika, zberigannja, klinichne zastosuvannja Пуповинна кров: медико-біологічна характеристика, зберігання, клінічне застосування [Umbilical cord blood: medical and biological characterization, storage and clinical application]. Zhinochij likar - Female doctor, 2009; 5: 53-56.

4. Nasadyuk CM. Stovburovi klitini pupovinnoï krovi v regenerativnij terapiï hvorob sercevo-sudinnoï sistemi [Cord blood stem cells in regenerative therapy of diseases of the cardiovascular system]. Zhinochij likar - Female doctor, 2009; 6:48 - 51 .

5. Obzor dokladov, predstavlennyh na Vsemirnom kongresse po pupovinnoj krovi i innovacionnym podhodam k lecheniju serpovidnokletochnoj anemii v Monako 24-27 oktjabrja 2013 goda [Overview of the Word Congress on Cord Blood and Innovative Approaches to The Treatment of Sickle-Cell Anemia in Monaco on 24-27 th October 2013]. Kletochnaja i organnaja transplantologija - Cell and organ transplantology, 2014; 2(1):90-94.

6. Abumaree M H, Jumah A I. The Immunomodulatory and Neuroprotective Effects of Mesenchymal Stem Cells (MSCs) in Experimental Autoimmune Encephalomyelitis (EAE): A Model of Multiple Sclerosis (MS). Int J Mol Sci. 2012; 13(7): 9298 - 9331.

7. Barcena A, Muench MO, Kapidzic M. Human placenta and chorion: potential additional sources of hematopoietic stem cells for transplantation. Transfusion. 2011; 51(4): 94S-105S.

8. Chakraborty PD, De D, Bandyopadhyay S, et al. Human aqueous placental extract as a wound healer. J. Wound Care. 2009; 18:462-467.

9. Chen J, Shehadah A, Pal A, et al. Neuroprotective effect of human placenta-derived cell treatment of stroke in rats. Cell Transplant. 2013; $22(5): 871$.

10. Fan $Z X, L u Y$, Deng L, et al. Placenta- versus bone-marrow-derived mesenchymal cells for the repair of segmental bone defects in a rabbit model. FEBS J. 2012; 279(13): 2455-2465.

11. Fazekasova $H$, Lechler $R$, Langford $K$, et al. Placenta derived MSCs are partially immunogenic and less immunomodulatory than bone marrow-derived MSCs J. Tissue Eng and Regen Med. 2011; 5(9): 684-694.

12. Fisher-Shoval Y, Barhum Y, Sadan O, et al. Transplantation of placenta-derived mesenchymal stem cells in the EAE mouse model of MS. J. Mol. Neurosci. 2012; 48(1): 176-184.

13. Ilic N, Brooke G, Murray P, et al. Manufacture of clinical grade human placenta-derived multipotent mesenchymal stromal cells. Methods Mol. Biol. 2011; 698: 89-106.

14. Lee JM, Jung J, Lee HJ, et al. Comparison of immunomodulatory effects of placenta mesenchymal stem cells with bone marrow and adipose mesenchymal stem cells. Int. Immunopharmacol. 2012; 13(2): 219-224.

15. Lee HJ, Jung J, Cho KJ, et al. Comparison of in vitro hepatogenic differentiation potential between various placenta-derived stem cells and other adult stem cells as an alternative source of functional hepatocytes. Differentiation. 2012; 84(3): 223-231.

16. Li F, Chen YZ, Miao ZN, et al. Human placenta-derived mesenchymal stem cells with silk fibroin biomaterial in the repair of articular cartilage defects. Cell Reprogram. 2012; 14(4): 334-341.

17. Li K, Li SZ, Zhang YL, et al. The effects of dan-shen root on cardiomyogenic differentiation of human placenta-derived mesenchymal stem cells. Biochem. Biophys. Res. Commun. 2011; 415(1):147-151.

18. Li J, Zhang H, Liu G. Research on anti-aging effect of mouse placenta cells transplantation. Sheng Wu Yi Xue Gong Cheng Xue Za Zhi. 2010; 27(6):1312-6.

19. Lu GH, Yong WS, Xu ZM, et al. H. Human placental decidua basalis-derived mesenchymal stem cells differentiate into dopamine neuron-like cells with no response to long-term culture in vitro. Neuroreport. 2012; 30(23): 513-518.

20. Malek A, Bersinger NA. Human placental stem cells: biomedical potential and clinical relevance. J. Stem Cells. 2011; 6(2): 75-92.

21. Oh EJ, Kim TK, Shin JH, et al. Biologic filler using human fibroblasts and placenta extracts. J. Craniofac. Surg. 2011; 22(5): 1557-1560.

22. Park S, Kim E, Koh SE. Dopaminergic differentiation of neural progenitors derived from placental mesenchymal stem cells in the brains of Parkinson's disease model rats and alleviation of asymmetric rotational behavior. Brain Res. 2012; 1466: 158-166.

23. Prather WR, Toren A, Meiron M, et al. The role of placental-derived adherent stromal cell (PLX-PAD) in the treatment of critical limb ischemia. Cytotherapy. 2009; 11(4): 427-34.

24. Sun NZ, Ji H. In vitro differentiation of osteocytes and adipocytes from human placenta-derived cells. J. Int. Med. Res. 2012; 40(2): 761-767.

25. Takeda $Y$, Uemura $S$, Iwama $H$, et al. Treatment with recombinant placental growth factor (PIGF) enhances both angiogenesis and arterogenesis andimproves survival after myocardial infarction. Circ. J. 2009; 73(9): 1674-1682. 
26. Young PP,SchäferR. Cell-based therapies for cardiac disease: a cellular therapist's perspective Transfusion. 2014. http://www.ncbi.nlm.nih.gov/pubmed/?term=Cellbased+therapies+for+cardiac+disease $\% 3 \mathrm{~A}+\mathrm{a}+$ cellular+therapist $\% 27 \mathrm{~s}+$ perspective.

27. Zhang D, Tong A, Zhou L, et al. Osteogenic differentiation of human placenta-derived mesenchymal stem cells (PMSCs) on electrospun nanofiber meshes. Cytotechnology. 2012; 64(6): 701-710.

28. Zhong ZN, Zhu SF, Yuan AD, et al. Potential of placenta-derive mesenchymal stem cells for bone tissue engineering: preliminary study of osteoblastic differentiation and immunogenicity. Orthopedics. 2012; 35(9):779-788.

29. http://clinicaltrials.gov/

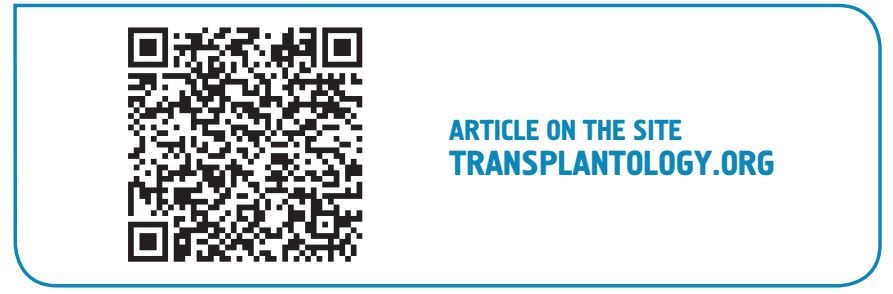

The author indicates no potential conflicts of interest.

Received: September 08, 2014

Accepted: October 27, 2014 